\title{
Union modernisation, coalitions and vulnerable work in the construction sector in Britain
}

\section{Document Version}

Accepted author manuscript

Link to publication record in Manchester Research Explorer

\section{Citation for published version (APA):}

Mustchin, S. (2014). Union modernisation, coalitions and vulnerable work in the construction sector in Britain. Industrial Relations Journal, 45(2), 121-136.

\section{Published in:}

Industrial Relations Journal

\section{Citing this paper}

Please note that where the full-text provided on Manchester Research Explorer is the Author Accepted Manuscript or Proof version this may differ from the final Published version. If citing, it is advised that you check and use the publisher's definitive version.

\section{General rights}

Copyright and moral rights for the publications made accessible in the Research Explorer are retained by the authors and/or other copyright owners and it is a condition of accessing publications that users recognise and abide by the legal requirements associated with these rights.

\section{Takedown policy}

If you believe that this document breaches copyright please refer to the University of Manchester's Takedown Procedures [http://man.ac.uk/04Y6Bo] or contact uml.scholarlycommunications@manchester.ac.uk providing relevant details, so we can investigate your claim.

\section{OPEN ACCESS}




\title{
Union modernisation, coalitions and vulnerable work in the construction sector in Britain
}

\author{
Published in Industrial Relations Journal (2014) 45:2. 121-136 - AAM \\ version
}

Stephen Mustchin

\begin{abstract}
This article analyses vulnerable work in the construction sector, the impact of the recession and union responses to these problems including the development of coalitions with civil society and state organisations, and provision of new services to members and other workers faced with heightened vulnerability at work. The case study is based on qualitative interviews and internal documentation, and focuses on the construction union, Union of Construction, Allied Technicians and Trades, and its work supported by the government-backed Union Modernisation Fund. The findings demonstrate some innovative approaches to supporting workers facing vulnerability in terms of job insecurity, health and safety and other problems, including drawing on support from other organisations with specific expertise and resources. Problems in terms of the political contingency of these links, vulnerability in terms of changing funding regimes and priorities within state agencies, and the vast scale of the problem of vulnerability at work are also highly prominent.
\end{abstract}

\section{INTRODUCTION}

This article analyses union responses to vulnerable work in the construction sector, including the development of coalitions with other actors to address these issues. There has been an increasing emphasis on precarious or vulnerable work in the academic literature (e.g. Kalleberg, 2009; Pollert and Charlwood, 2009; Standing, 2011). Casualised employment has long been prevalent in the construction industry, which suffers relatively high injury and fatality rates. Further dimensions of vulnerability include employment law abuses, casualised employment status, fragmented employer structure, specific problems faced by migrant workers, the weakly regulated role of gangmasters, blacklisting, issues relating to skills and accreditation, and demand fluctuations caused by recession and austerity.

The union initiative analysed in this article attempted to address many of these wide-ranging dimensions of vulnerability by supporting construction workers beyond their core membership, developing links with state agencies and civil society organisations (CSOs), developing new services to support workers facing redundancy, and

Stephen Mustchin is Lecturer in Employment Studies, Manchester Business School, University of Manchester. Correspondence should be addressed to Stephen Mustchin, Manchester Business School, University of Manchester, Manchester M15 6PB, UK; email: stephen.mustchin@ manchester.ac.uk 
internal union changes to attempt to make the union more responsive to vulnerable workers. The analysis focuses on the Union of Construction, Allied Technicians and Trades (UCATT) and its work within Round Three of the government-funded Union Modernisation Fund (UMF), which focused on problems of 'vulnerability' at work. It is argued that, while coalitions with CSOs can contribute significantly to supporting union aims, state agencies arguably play a more significant role; widespread abuses of employment regulation, particularly in construction, necessitate harder forms of regulation and more enforcement capacity than CSOs can offer. This raises questions about the position of unions with regard to the state, how they engage with regulatory actors and CSOs, new service provision for members, and how unions might support vulnerable workers who generally fall outside of established forms of joint regulation at the workplace or firm level. The article firstly addresses vulnerable work, the construction sector context, and policy and union responses, including the development of coalitions with other actors. This is followed by the case study analysis, discussion and conclusions.

\section{VULNERABILITY AT WORK AND IN THE CONSTRUCTION SECTOR}

Notions of precarity or vulnerability at work are wide ranging and therefore problematic in analytical terms, but are broadly concerned with insecure, weakly regulated and generally low-paid employment. Precarity arises due to job loss, fear of job loss, limited alternative labour market opportunities, limited opportunities to gain and maintain skills, income insecurity, unsafe work, and lack of collective voice (Kalleberg, 2009; Standing, 2011). These conditions are particularly apparent in the construction industry (and much of the wider labour market), so the novelty of 'precariousness' as a phenomenon is questionable. Construction workers working for agencies, subcontractors or with self-employed status have suffered more immediately than directly employed workers during the post-2008 recession as employers have externalised the impact of demand fluctuations from their directly employed workforce (MacKenzie et al., 2010). Main contractors typically manage projects but rely on subcontractors, gangmasters and agencies to supply labour (Cremers, 2009: 211-212).

The UK construction sector employs, as of December 2012, 1.989 million workers - this has fallen from a peak of 2.352 million workers in the third quarter of 2008 (ONS, 2012). Manual occupations account for 49 per cent of this overall number, with 70 per cent of manual workers holding employee status, 25 per cent counted as self-employed and five per cent in trainee roles (CITB, 2012). Job losses, insolvencies and a widening gap in wage levels between skilled and semi/unskilled workers have been prevalent in the construction industry in the post-2008 period (Chan and McCabe, 2010: 529-530). 'False' self-employment is widespread in construction, with around a fifth of workers in the sector classed as self-employed but working consistently for the same firm, often for long periods of time, allowing employers to avoid non-wage costs such as employee National Insurance contributions and other liabilities (Harvey and Behling, 2008). Increased use of labour-only subcontracting in the industry since the early 1970s is a result of firms prioritising flexibility over productivity as a source of competitive advantage: 'a form of abdication of control over the actual labour process by construction employers, and a retreat to a reliance on control through the labour market, in what can be called "market control" of the labour process' (Winch, 1998: 539). 
The casualised nature of much construction employment in Britain is argued to contribute to lower levels of productivity compared with other European countries (Bosch and Philips, 2003), although casualisation and non-direct forms of construction employment are increasingly common in more regulated states such as Sweden (MacKenzie et al., 2010). Firms typically rely on external rather than internal labour markets, 'poaching' skilled workers, and using informal recruitment practices that often exclude women and ethnic minorities (Clarke and Herrmann, 2007: 524). Health and safety problems are common in the construction industry, with relatively high levels of injuries, illnesses and fatalities ( 70 per cent of which can be ascribed to management failures according to the Health and Safety Executive (HSE)), coterminous with falling numbers of prosecutions and HSE investigations (Mantouvalou, 2011: 17). Recent government reviews of health and safety regulation place a greater emphasis on self-reporting and reducing levels of unannounced HSE inspections of workplaces (Löfstedt, 2011). The approach to enforcement in the UK increasingly emphasises individual challenges to abuses of employment rights as opposed to more proactive approaches to inspection, monitoring and enforcement that address broader structural and organisational problems (Dickens, 2012: 206-207). State agencies are constrained in their ability to regulate an increasingly fragmented labour market, and it has been argued repeatedly that stronger union input into health and safety enforcement is vital if it is to be improved (e.g. Nichols, 1997).

Union density among construction workers fell from 30.4 to 14.8 per cent between 1995 and 2011; 18 per cent of workers in the industry had their pay set by collective bargaining and 27.3 per cent of construction workplaces had some union presence in 2011 (BIS, 2012). Although unions face major challenges in construction, UCATT (along with Unite and GMB) maintains collective agreements with many of the major construction firms in the UK, most notably under the National Agreement for the Engineering Construction Industry and the Construction Industry Joint Council. Disputes involving construction engineers in the energy sector (Gall, 2012) and the 2011/12 construction electricians' campaign demonstrate the capacity of typically more highly skilled and well-organised groups of workers to extract concessions from employers. However, the size of the non-unionised construction workforce suggests a need for innovative approaches from unions if they are to meaningfully support them.

\section{UNION AND POLICY RESPONSES TO VULNERABLE WORK}

Vulnerable work became increasingly prominent within policy and union debates during the 2005-10 Labour government, and was identified as a policy priority in the 2004 Warwick Agreement between Labour and affiliated unions. The TUC established the Commission on Vulnerable Employment in 2007 to gather evidence and make policy recommendations. Competing definitions acknowledge similar problems of weak legal protection for workers, employer exploitation of these weaknesses and low levels of union representation, with the TUC defining vulnerability as stemming from the 'imbalance of power in the employer-workers relationship' (TUC, 2007: 3); and the government deeming this to be problematic only 'if an employer exploits that vulnerability' (DTI, 2006: 25). Broader definitions of vulnerability include all lowpaid, unrepresented workers, a far higher proportion of the workforce than the 2 million vulnerable workers identified by the TUC, with major difficulties faced by vulnerable workers in attempting to enforce their rights at work and few sources of support (Pollert and Charlwood, 2009: 354). 
This debate led to (limited) government support for pilot projects where unions, enforcement agencies, employers, training providers, advice services, voluntary organisations and others worked together to provide sources of advice and support for vulnerable workers (Shearn et al., 2010). This was reflected in the emphasis on vulnerability within the final round of UMF projects. The UMF allocated 67 grants totalling over $£ 7$ million before its abolition in 2010, and it has been argued to have led to 'substantial improvements in the professionalism of most of the larger trade unions' (Brown, 2011: 406-407). The UMF has been criticised both as: 'cash incentives to turn away from adversarialism' (McIlroy, 2009: 87), and 'taxpayers' money . . . being handed to trade union bosses by Labour ministers reliant on union donations' (Conservative Party, 2010). The extent to which relatively small, dispersed UMF grants had any moderating effect on unions and their members is doubtful, and the sizeable number of UMF projects run by non-Labour-affiliated unions further undermines these criticisms. Detailed evaluations of the first two rounds took place (Stuart et al., 2010) but there is little detailed research on projects funded through Round Three due to the abolition of the UMF. This case study partially addresses this gap in the literature.

The main priorities of the first two rounds of the UMF included: improving communications between unions and their members; developing the professionalism of union officers and 'modernising' internal management practices; improving the ability of unions to support an increasingly diverse workforce; and, introduced in Round Two, the development of workplace equality representatives (Stuart et al., 2010; 2013). In Round Three there was a change of emphasis to a narrower, less managerial set of themes, including working with government agencies and CSOs to address vulnerability at work; developing new services for vulnerable workers; and raising the profile of issues of vulnerability within unions. Organising, recruitment, political activity and support for industrial action were excluded from UMF projects as a condition of the funding. Projects funded by Round Three of the UMF that focused on vulnerability included work within Unison, Union of Shop, Distributive and Allied Workers (USDAW), General, Municipal and Boilermakers Union (GMB), General Federation of Trade Unions (GFTU), National Union of Journalists (NUJ), National Union of Rail, Maritime and Transport Workers (RMT), Transport Salaried Staffs' Association (TSSA), Bakers, Food and Allied Workers Union (BFAWU), Community and the TUC. Some of these projects focused on particular groups that face vulnerability at work including young workers, migrant workers, freelancers and outsourced workers. The RMT project focused on vulnerable work among outsourced workers and the low paid within the rail industry, raising awareness of the problems they face within the union and engaging with advice and support services to address these concerns. A similarly broad approach to vulnerability at work informed the ambitious aims and objectives of the UCATT Vulnerable Workers Unit (VWU) project. Notably, there was little emphasis in Round Three on notions of partnership with employers, in contrast to earlier rounds.

Partnerships or coalitions including unions, CSOs and state agencies concerned with aspects of employment were a key priority of Round Three of the UMF. Innovative, networked forms of union organisation to support workers in vulnerable employment have been advocated in light of the decline of more 'traditional institutional sources of union power' (Tattersall, 2009: 489). Union-CSO coalitions have also been advocated in the United States as a means of supporting workers and improving enforcement of employment rights (e.g. Bernhardt et al., 2009; Fine and 
Gordon, 2010). Union engagement with CSOs can improve the capacity of unions to represent and support vulnerable workers, and working with 'issue-specific' CSOs can allow unions to draw on valuable specialist expertise that they may not otherwise hold (Gumbrell-McCormick and Hyman, 2013: 145-151). Three key types of union-led coalitions include: vanguard coalitions, where organisations offer support to unions including solidarity action, usually during major disputes; common cause coalitions, where unions and others identify separate but associated interests and work in concert to address them; and integrative coalitions where unions adopt the objectives of non-labour movement bodies as their own, as with campaigns relating to equality and combating discrimination; significantly, these definitions explicitly exclude state agencies in favour of a focus on CSOs and social movements (Frege et al., 2004: 139-143). In recent years CSOs in the UK have been increasingly involved in social policy delivery and have received significant amounts of state funding (Davies, 2008). Clear distinctions between the state and CSOs are therefore problematic, and union coalitions with CSOs will inevitably lead to some engagement with state funding and regulatory actors, which has arguably been underemphasised in the literature on community unionism and union-led coalitions.

Problems identified within coalitions formed around living wage campaigns in the United States include the significant energy expended on localised activity focused on relatively small numbers of workers considering the scale of the problem of low pay in the wider labour market; 'scaling up' such campaigns necessitates wider, more permanent alliances between unions and other organisations rather than time-limited coalitions with a localised, micro-focus (Freeman, 2005). In the UK, links between community organisations, advice services and unions are relatively uncommon and, where they do occur, are reliant on very specific local networks and contingencies (Holgate et al., 2012: 626). CSOs, many of which have some interest in employmentrelated matters including advocacy for particular groups, rights at work, equality and discrimination, and training, are argued to represent new industrial relations actors that have become more focused on work and employment as a consequence of wider union decline, within 'a more complex, multiform system of worker representation that also comprises employer-sponsored worker involvement, statutory forms of worker representation, private representation through lawyers and other advocates, government inspection agencies and trade unionism' (Heery et al., 2012: 23).

The ambitious, wide-ranging project focused on in this case study addressed many of these themes. UCATT's UMF-supported VWU project had a major emphasis on strengthening links with CSOs and state agencies to support vulnerable workers. Two main research questions are addressed. First, how is vulnerability at work experienced within the construction sector, and how might unions address these issues? Second, what impact does the formation of union-led coalitions involving CSOs and other agencies have on the support unions can offer to vulnerable workers? This second question allows for some analysis of the dynamics of union engagement with the state, which has been critiqued as diluting the independence of unions and leading to risks related to co-option (e.g. McIlroy, 2009). Research methods are outlined in the next section, followed by case study analysis, discussion and conclusion.

\section{RESEARCH METHODS}

This research was based on analysis of a wide range of internal documentation provided by the union (including data on outcomes and numbers of workers 
supported, internal reports and reviews of progress), observation of meetings and steering groups, a total of 18 formal interviews and numerous less formal discussions that took place during evaluations of the union's UMF supported work between 2009 and 2012, including an earlier, small-scale research report at the end of the union's Round Two UMF project. This formed the basis for an end-of-project study analysing the impact and effectiveness of the Round Three UMF project. The research analysed the project's outcomes in relation to its funding levels, initial aims and objectives, including numbers assisted by the project, links with outside organisations, developing new communication materials, working with employers and within workplaces, change within the union deriving from this work, and internal and external challenges faced. This study highlighted how the project raised the level of support they were able to offer workers affected by vulnerability, the role of coalitions in supporting this work, and the dynamics of engaging with both state and non-state actors. Interviews focused on how interviewees understood the concept of vulnerable work, how vulnerability was manifested in the sector, the union response, additional benefits gained by the union from the support of the UMF, and the formation of coalitions with other bodies concerned with labour market and employment matters. Interviewees included five full-time officials of the union, two union project workers, three convenors from UCATT-organised workplaces, four project workers from other unions involved in Round Three of the UMF and four representatives of partner organisations. The interviews provided insights into how coalitions were developed, what advantages this work brought to the union, as well as detailed reflections on vulnerability, the role of employers and employment status in driving vulnerability at work, and reflections on how the recession and the actions of the state had impacted on these problems.

\section{UNION REPRESENTATION AND VULNERABILITY IN THE CONSTRUCTION SECTOR}

UCATT has approximately 84,000 members (Certification Officer, 2011). This case study focuses particularly on work carried out under Round Three (2009-2011) of the UMF. In the years prior to UCATT's involvement with the UMF, internal changes had been made to address the challenges faced by the union and workers in the construction sector, including a stronger emphasis on membership growth with full time officers (FTOs) now working with recruitment targets, Union Learning Fund projects, the development of links with CSOs concerned with employment, safety problems in the construction sector and migrant workers, and political campaigns aiming to improve regulation and employment conditions in the sector.

Work carried out by UCATT under Round Two of the UMF (2007-2009) had provided a platform for this later project, promoting changes to the union's administration and its officer training, engagement with employers, and improved communication between the various levels of the organisation. Some working methods within the union were described by a national official as 'no longer fit for purpose', with a regional secretary highlighting how 'full-time officials ... have come from the construction industry - they are building workers and office and organisational skills are often pushed to one side'. These internal changes were the foundation for the establishment of the UCATT VWU, set up with $£ 278,000$ allocated from Round Three of the UMF. This was initially staffed by two project workers and an administrator based in the union's Midlands regional office in Derby, the focal point for the 
provision of information, advice and guidance (IAG) services to officers and reps within the union, vulnerable workers, and UCATT members generally. Young, innovative project workers from outside of the union's traditional representative structures were of crucial importance to the project. Towards the end of the research UCATT experienced considerable upheaval at national level, including repeated general secretary elections due to balloting irregularities, and a series of employment tribunals and legal challenges pursued by former officials of the union. These developments are largely beyond the scope of this article, as the regional office location and project-based nature of the VWU largely insulated it from these problems.

The VWU addressed a broad spectrum of vulnerabilities by developing relationships with state and voluntary organisations including the employment service Jobcentre Plus; the state-funded financial advice body Money Advice Service; the charity Community Links; the union's solicitors and other legal advice services; Citizens Advice Bureaux (CAB); local asbestosis support groups; the Connexions and Next Step careers advice services; further education colleges, and statutory agencies concerned with employment rights including the Gangmasters Licensing Authority (GLA), Employment Agency Standards Inspectorate (EASI), Health and Safety Executive (HSE), and HM Revenue and Customs (HMRC). The union had also made links with Polish organisations and others representing particular nationalities in the UK to support migrant workers. The work of these partner organisations was viewed as 'essential to the project. All of them have added their expertise and support. Without any of them really we would have struggled ... although we have a broad knowledge base, we're not specific... we can't know everything' (VWU project worker).

The nature of these relationships varied. Formal protocols were agreed with the HSE over information sharing and some joint work in supporting vulnerable workers. Organisations including the union's solicitors, Money Advice Service and the charities involved worked with the union on developing information resources for vulnerable workers. Collaborations ranged from the relatively informal to the more substantive, and were not all new or solely a result of the VWU's work, but the VWU allowed for collaboration and dialogue focused on vulnerability that went beyond the often more ad hoc relationships that existed previously. Formalised collaborative work was apparent in the involvement of these partner organisations in regular steering group meetings and their participation in the one-day events held within workplaces undergoing redundancy. These events involved partner organisations providing specific expertise and support relating to employment rights, training and skills, health and safety, finding work, benefits and finance. State-supported partner agencies such as advice services and Jobcentre Plus were mainly involved in these workplace-based events, and had the capacity and remit to do so in large part due to specific funding allocated to them by government to support workers affected by recession between 2008 and 2010. A major focus of the unit was to provide advice through drop-in sessions, by telephone and by email from its base in the union's regional office.

The work of the VWU, the extra capacity it brought and the alliances it facilitated was seen as highly valuable within the union:

(W)e were going through the recession, and a lot of the VWU's time was taken up with helping people who had unfortunately found themselves in a situation of being made redundant ... that allowed the officials to get on with other jobs ... the officials wouldn't have been able to fill that hole that the VWU has filled [UCATT regional secretary]. 
The VWU recorded 18,439 instances of dissemination of its IAG materials, and significant numbers of workers (456) received assistance through the one-day sessions providing support to workers facing redundancy. The unit provided advice and support to 221 construction apprentices. Of the approximately 400 enquiries made to the VWU advice line, 48 per cent related to redundancy, 17 per cent to employment rights, 12 per cent to finance and benefits, 14 per cent to finding work, and 8 per cent to training and skills. Nearly 3,000 individuals were provided with direct support from the unit beyond the provision of IAG materials, a relatively high figure given the financial constraints faced by the unit and the challenge of expanding its work beyond the core areas and regions where it operated. Fewer than 200 workers directly attended drop-in events at the VWU headquarters in the union's regional office, a relatively low figure but perhaps unsurprising, given the temporary nature of construction workplaces and the size of the region. Ambitious initial plans to upscale the project throughout the union nationally were not fully realised. Some significant work was carried out in both London and the North West, with particular individuals within these union regions engaging closely with the VWU, but the limited resources and timescale of the project meant that it did not expand markedly beyond these regions.

\section{INSECURE AND VULNERABLE WORKERS IN THE CONSTRUCTION SECTOR}

This section addresses the first research question: How is vulnerability at work experienced within the construction sector, and how might unions address these issues? A holistic approach was adopted through the VWU project that provided support for both members and non-members over a wide range of vulnerabilities: 'we have gone broader than the other unions... with construction you've got bogus selfemployment, you've got blacklisting . . . issues around health and safety and asbestosis related illnesses. You've got much more there where people would become vulnerable' (VWU project worker). Approximately a quarter of those approaching the unit were not members of any union, and significant numbers of non-UCATT union members had approached the VWU due to a lack of support from their own unions. Migrant workers, apprentices, workers facing redundancy, older workers, workers with low levels of qualifications, women working in construction, workers suffering from industrial injuries and diseases, workers facing bullying and harassment, blacklisted workers, and night-shift workers were further groups identified as vulnerable. These problems of vulnerability are entrenched in construction. The relative power of construction employers (within the employment relationship and politically), and the savings they made through weakly regulated, fragmented forms of employment in the sector, were identified as major drivers of vulnerability. Interviewees were asked whether the term 'vulnerable' had met any resistance or criticisms from workers, but this had seemingly been broadly accepted: 'if you're put at risk either to be transferred or redundant, you know yourself you're bloody vulnerable' (UCATT convenor).

Reduced construction activity in the post-2008 period had led to increased competition in the sector, with firms increasingly subcontracting to reduce non-wage costs and undercut firms that maintained direct employment. Data from 2008 suggest that approximately 300,000 construction workers are 'genuinely' self-employed, with a further 400,000 workers operating with 'false' self-employed status, where this status has been promoted by employers as a means of avoiding non-wage costs; given the 
large 'hidden' dimension of the construction workforce, these figures are likely to be conservative (Harvey and Behling, 2008: iv). Insecurity was increasingly apparent in ostensibly more secure areas of construction employment, such as the local authority housing sector, which has mostly been privatised by arm's length management organisations and housing associations. Workers would commonly be engaged by these employers under self-employed status and could be dismissed without notice or redundancy pay. Tensions between the work of the VWU, other unions and management were noted in local government. A convenor in this sector noted that other, larger public sector unions had struggled to gain the trust and support of workers being made redundant as these unions represented some in managerial or HR roles that were directly involved in the process of redundancy consultation and selection, as well as in the privatisation of council housing which often had a negative impact on the employment status of UCATT members. While some success was evident from UCATT's engagement with other bodies, working with other unions was evidently problematic where their interests overlapped and sometimes conflicted.

A further example of the exceptional nature of the industry can be seen in the treatment of labour-only subcontractors or gangmasters. Examples were given of migrant workers 'employed' by gangmasters, including on large public infrastructure projects, where accommodation, transport and other deductions had meant they took home $£ 8$ per week, with significant difficulties for the union in trying to represent these workers due to problems including immigration status, confiscation by the gangmaster of passports and general fear of those in the gangmaster role, who sometimes had links to organised crime including human trafficking. Minimum wage legislation was commonly breached in these circumstances. The 2004 Gangmasters Licensing Act does not apply in the construction sector following successful industry lobbying at the time of the legislation, with casualisation an enduring problem.

Young workers and apprentices were a further group identified as vulnerable. Recession and austerity meant that large numbers of apprentices were discarded following their apprenticeships, and low awareness of employment rights was common. The new model of apprenticeships introduced since 2010 was criticised as yet another means of casualising the construction workforce, as they were typically of shorter duration and involved less commitment from employers than in the past. Some larger employers actively welcomed the union coming in to speak to construction apprentices, but others were hostile and some colleges would prevent the union from approaching them. Apprentices on placement were often treated badly, and the VWU had provided a basis for the union to engage in casework supporting apprentices who were unfairly treated. Redundancy was a major focus of the VWU's work, particularly in light of the recession and the subsequent contraction of the construction workforce. Services offered to those facing redundancy included: advice on finding other jobs; issues relating to personal finances and claiming benefits; legal advice regarding redundancy consultations, TUPE, temporary lay-offs and shorttime working; and providing advice on and access to training and accreditation, CV writing and interview skills. The VWU had been active within a number of major public and private sector employers undergoing redundancies, with employers praising the 'excellent support' offered and the speed and efficiency with which the events had been organised: 'the feedback that came back was phenomenal, on how helpful it had all been, they wouldn't have known that most of these initiatives existed had it not been for UCATT ... it wasn't patronising, it was very, very valuable' (Training manager). Recruitment was separate to the work of the VWU, but it was felt that 
improved perceptions of the union led to improved retention of members who were laid off or changing employers. A convenor at a major construction firm compared this holistic approach favourably with previous initiatives the firm had set up when faced with redundancy situations, noting examples where they "might offer a job fair, but very little jobs ever came from that . . . it was just like advertising . . . a lot of them were agencies, "you sign up with us and then we'll get back to you, possibly" '. The HR department at this convenor's employer had attempted to take more credit in organising the redundancy events than they were due: 'they want to take all the praise from it now'. While management allowed access and provided a room for the events, they did very little in terms of organisation which was driven by the union, the VWU and partner organisations.

Overall, employment status was key to employers' 'market control' (Winch, 1998: 539) of the labour process, and the main driver behind the high levels of vulnerability faced by much of the construction workforce. The VWU addressed many of these problems relating to casualisation. The next section focuses on health and safety, a further highly significant area of vulnerability that is of particular concern within construction, along with wider relationships with partner organisations and the role of the state.

\section{HEALTH AND SAFETY, ENFORCEMENT AND COALITIONS WITH STATE AND NON-STATE AGENCIES}

This section addresses the second research question: What impact does the formation of union-led coalitions involving CSOs and other agencies have on the support unions can offer to vulnerable workers? The UK construction industry was highlighted for its high levels of casualties and the relative weakness of regulation in the sector. Construction accounts for 27 per cent of fatal injuries to employees and 10 per cent of reported major injuries, with an average of 53 deaths per year and 31,000 new cases of work-related ill health reported in 2012 (HSE, 2013: 2). Health and safety regimes were challenged by the proliferation of casualised workers, and managers, especially supervisors and foremen, often failed to address these problems. Lack of sick pay led to workers attending despite suffering from illness, exacerbating their conditions and contributing towards premature exit from the industry. These practices place enormous physical and financial stress on construction workers, with state benefits and pensions being left to fill the gap once workers are discarded or unable to work in the industry any longer.

The fragmented nature of enforcement agencies in the UK is problematic; the GLA has no remit in construction, HMRC prosecutions of minimum wage abuses are notoriously uncommon, and EASI was felt to be under-resourced and to have little influence in the sector. Close links were developed with an outreach worker from the HSE who had a remit to focus on vulnerability at work:

(I)f I had some cases that I couldn't help with, I would send them to the Vulnerable Workers Unit . . . as a signposting thing. So if UCATT would have problems, they would tell the HSE which would take enforcement action ... we actually can make a difference because we allow them to get the powers to intervene ... the biggest difference between HSE and the work outreach workers are doing in other organisations, such as CAB or ACAS [is that] they can mediate, they can advise, but they can't take any further action [Project worker, HSE].

Regular sessions for migrant workers were held at the VWU with this HSE outreach worker present, and this interviewee noted the benefits this gave in terms of 
providing an open, multilingual support service for advice on health and safety matters, but also in terms of bringing problems to the attention of the HSE where enforcement action could be taken. Small workplaces and other establishments that employed high numbers of migrant workers often had problems in this area and the union-HSE links established through the VWU were beneficial in terms of gathering intelligence on employers who may have been breaching their legal responsibilities. General problems at work were often connected to wider problems in terms of employment rights and health and safety:

(U)sually when you have issues related to employment, you will have issues related with working time
regulations... There are over five agencies enforcing different bits of working time regulations. So
we're not always able to intervene ourselves and it gives us a good indication ... if they are breaking
that, there's a high chance they won't be compliant in other areas of law or other areas of health and
safety... . [but] it's very unsteady employment and people are even more scared to com-
plain ... Because they don't have a guaranteed job and they don't want to lose it [Project worker, HSE].

The distrust faced by state agencies such as the HSE was, to an extent, overcome by these closer forms of working with UCATT:

(P)eople are always scared to contact the agency . . . there are some preconceptions about us, you know, we get there and we shut the factory down because it's so bad . . . and everyone loses their jobs, that's people's impression ... it's difficult to gain the trust of people so when someone who they trust refers them ... it's always easier [Project worker, HSE].

Innovative links with enforcement bodies are a key example of how the work of the VWU allowed for more cooperation between the union and state agencies, work that focused on the frontline or workplace level rather than in more distant policy bodies. This led to a more proactive approach to enforcement than the more individualised policy discourse argued elsewhere to undermine the regulation of rights at work (Dickens, 2012). However, regulatory changes reducing the frequency of inspections, the broad nature of problems faced and cuts in resources for the HSE meant that these dimensions of vulnerability were increasingly difficult to address: 'if there's no deterrent there, we can only see that getting worse and we're predicting that the death toll will start to rise in construction' (UCATT convenor).

All of the agencies involved in the project experienced problems during the lifetime of the VWU due to cuts in their budgets (and abolition in some cases) from 2010 onwards. Legal services and charities were the main organisations engaged with that received minimal state support - referrals were made to charities, and legal representation was brought in for workers via the VWU, and while these relationships were less politically contingent than those with bodies more reliant on state funding, limited union resources to pay for such services meant that their impact was constrained. The VWU had originally aspired to strengthen links between the union and enforcement agencies, and while this worked well in terms of the HSE who had devoted funding for outreach workers focused on vulnerable and migrant workers, working with EASI and HMRC was more problematic due to their lack of resources. Attempts to link up these bodies were undermined by the fragmentation of the inspection system and constraints deriving from the cuts made to their funding from 2010 onwards. Other state agencies such as professional advice services provided a great deal of benefit to the activity of the VWU, but again this was challenged by funding cuts to and abolition of some of these bodies.

Nonetheless, these links were seen as one of the most significant new ways of working arising from the project, and despite the challenges faced by the partner agencies, this engagement was envisaged to continue beyond the lifetime of the 
project. There was a commitment to ensuring the work of the VWU could be adopted by other regions of the union, through the literature and training modules on issues facing vulnerable workers developed by the unit. Some tensions undoubtedly arose from engaging with state agencies, including the caution vulnerable workers felt in approaching organisations with the capacity to shut down their employer or who may have links to the benefits or immigration system, leading to an inevitable lack of trust. Cuts in resources for many of these agencies, as well as those faced by CSOs which receive state subsidies, and the fragility of relationships between organisations which often rely on individuals with the motivation and capacity to get involved in such coalitions, meant that sustaining this kind of work is problematic and inherently fragile. However, the union was the lead actor within these coalitions, and there was no suggestion that the union was weakened, compromised or dragged in directions counter to their core objectives as a consequence of engaging with the state in this case.

\section{DISCUSSION}

This case study provides insights on a number of themes including: the nature of the employment relationship and labour process in construction and the impact of the recession on employment in the sector; the problematic nature of regulation and enforcement in the sector; the difficulties faced by unions in attempting to address these problems; and the nature of the coalitions that they may form to address them, including the problematic subject of engaging with state agencies.

The first research question explored how vulnerability at work is experienced within the construction sector, and how unions might address these issues. A wide range of vulnerabilities are faced by construction workers; the key points in various other definitions of vulnerability (DTI, 2006; TUC, 2007) and precarity at work (Kalleberg, 2009; Standing, 2011) are particularly acute in construction. 'Market control' of the labour process (Winch, 1998), construction employers' perpetuation of casualised employment, their power to lobby against and resist stronger forms of regulation, and their involvement in blacklisting are indicative of the particular and enduring nature of vulnerable work in the sector. These vulnerabilities had been exacerbated by the recession and falling employment levels in the sector since late-2008. These material conditions in the sector present major challenges to unions, which have experienced significant falls in membership (BIS, 2012) and growing problems in terms of having the capacity to regulate the employment relationship in a fragmented context (Bosch and Philips, 2003). These conditions informed the approach taken by UCATT, and the VWU was an ambitious attempt to address multiple dimensions of vulnerability that went beyond what the union had the capacity to do prior to this work. The project could still only make a relatively limited contribution, given the vast scale of these problems.

The second research question addressed the impact of the formation of union-led coalitions involving CSOs and other agencies on the support unions can offer to vulnerable workers. These coalitions most resembled the 'common cause' or 'integrative' form of coalition identified elsewhere (Frege et al., 2004), but were mostly time limited and facilitated by politically contingent support for workers affected by vulnerability and recession, with insufficient resources for such work to be widely 'upscaled' (Freeman, 2005) in a way that would address the widespread problems faced by construction workers. Important links were made with a range of 
organisations, resonating with analyses of 'new actors' in industrial relations (Heery et al., 2012), but state agencies providing support on issues relating to redundancy were central to this work, as was engagement with bodies with the capacity to influence the regulation of employment. This included union solicitors and also enforcement agencies such as the HSE. The raised profile of vulnerability at work, which had been partly driven by union lobbying of the Labour Party and then raised further by problems arising from the post-2008 recession, was central to the links developed with other agencies in this case. UMF projects concerned with vulnerable work generally involved improved servicing functions as opposed to encouraging partnership with employers, unlike in the first and second rounds of the UMF and which has been critiqued in analyses of union engagement with the state in the New Labour period (McIlroy, 2009).

Shifting regulatory and institutional support was also a key dimension of this work: links with enforcement agencies such as the HSE had been strengthened through this project, and were motivated by widespread problems regarding basic enforcement of employment regulation. Contributions to the US literature on enforcement have advocated a stronger role for unions working in coalition with other agencies to address abuses of the law and to support workers outside of more regulated or unionised work environments (e.g. Bernhardt et al., 2009; Fine and Gordon, 2010). Although the union worked with a number of charities, campaigning organisations and other CSOs, the role of state-funded bodies such as enforcement agencies, education providers and employment services was arguably more significant. These agencies are clearly removed from the grassroots, campaigning bodies linked to bottom-up union campaigns envisaged in debates on community unionism linked to union revitalisation (e.g. Holgate et al., 2012; Martinez Lucio and Perrett, 2009; Tattersall, 2009). Such organisations often lack the capacity to support union aims of improving regulatory outcomes for workers. These agencies had received some funding for projects connected with job loss during the recession, but the post-2010 government has cut much of this funding and abolished a number of the agencies that were involved in the project, demonstrating the complexities and problems of sustainability inherent to working with state agencies. While the support they provided was valuable, stronger forms of intervention drawing on legal regulation and some degree of state funding appeared necessary if this work was to constitute more than advice services alone.

State funding through the UMF was fundamental to bringing together these diverse organisations. The impact and reach of the project was impressive, given the limited resources made available. This demonstrates that unions can play a valuable role in supply-side labour market policies aiming to mitigate the effects of recession on workers. The exclusion of unions from the policy process, especially under Conservative governments, means that an expansion of this kind of work is probably unlikely, and unions themselves would understandably be reluctant to engage in supply-side policies linked to increasingly punitive treatment of those facing redundancy and unemployment. The sustainability of the work of the VWU was undermined by the vulnerability of these partner organisations and the withdrawal of UMF funding, but the union had integrated some of these services into a reconfigured 'membership unit', retaining some of the project workers who were of critical importance to this work. The open approach to supporting vulnerable workers in construction embodied by this project is to be continued within the union, constituting a significant widening of the union's focus beyond more traditional workplace-oriented activity. 


\section{CONCLUSIONS}

Vulnerable employment is a perennial feature of the construction sector, and regula-tion through unions or via enforcement agencies is problematic due to the structure of the sector, its employment characteristics and the sheer breadth of problems faced. The scale of problems relating to vulnerability at work go beyond what small, often locally based CSOs may be able to achieve, and represent huge challenges to union organisation. Union coalitions may serve to increase capacity and improve the ability of both unions and enforcement agencies to support vulnerable workers, although tensions may arise from working with state agencies. Further problems in terms of sustainability are apparent in light of the budget cuts faced by enforcement agencies since 2010. More militant, oppositional approaches (such as the electricians' protests of 2012) are apparent elsewhere, among particularly skilled, well-organised groups of workers. These characteristics are not present in large parts of the construction workforce, suggesting that a wide range of union strategies including coalition build-ing and offering support beyond their core memberships are needed if the widespread problems of vulnerability in the sector are to be addressed.

\section{Acknowledgements}

The author would like to thank the editor and the two anonymous reviewers for their helpful comments, Miguel Martinez Lucio for comments on earlier drafts of the article, Steve Craig of UCATT and all of those interviewed, and the Fairness at Work Research Centre at Manchester Business School for support with research expenses.

\section{References}

Bernhardt, A., R. Milkman, N. Theodore, D. Heckathorn, M. Auer, J. DeFilippis, A. Gonzalez, V. Narro, J. Perelshteyn, D. Polson, M. Spiller, (2009), Broken Laws, Unprotected Workers: Violations of Employment and Labor Laws in America's Cities (New York, National Employment Law project).

BIS (2012), Trade Union Membership 2011 (London, Department of Business, Innovation and Skills).

Bosch, G. and P. Philips (eds) (2003), Building Chaos: An International Comparison of Deregu-lation in the Construction Industry (London, Routledge).

Brown, W. (2011), 'Industrial Relations in Britain under New Labour, 1997-2010: A Post Mortem', Journal of Industrial Relations, 53, 3, 402-413.

Certification Officer (2011), 'UCATT: Annual Return'. Retrieved April 2013 from http://www .certoffice.org/CertificationOfficer/media/DocumentLibrary/PDF/378T_2011.pdf

Chan, P. and S. McCabe (2010), 'Emerging Disparities: Exploring the Impacts of the Financial Crisis on the UK Construction Labour Market.' in C. Egbu (ed.), Proceedings of the 26th Annual Association of Researchers in Construction Management Conference, 6-8 September 2010, Leeds, UK.

CITB (2012), Survey of Employment by Occupation in the Construction Industry 2011 (London, NatCen Social Research).

Clarke, L. and G. Herrmann (2007), 'Skills Shortages, Recruitment and Retention in the House Building Sector', Personnel Review, 36, 4509-4527.

Conservative Party (2010), 'Labour Tax and Spending Lies: The Dodgy Dossier'. Retrieved June 2012 from http://m.conservatives.com/News/News_stories/2010/01/ /media/ A346FED512C24A2F9AC100726D0819FA.ashx 
Cremers, J. (2009), 'Changing Employment Patterns and Collective Bargaining: The Case of Construction', International Journal of Labour Research, 1, 2, 201-217.

Davies, S. (2008), 'Contracting out Employment Services to the Third and Private Sectors: A Critique', Critical Social Policy, 28, 2, 136-164.

Dickens, L. (2012), 'Fairer Workplaces: Making Employment Rights Effective', in L. Dickens (ed.), Making Employment Rights Effective: Issues of enforcement and compliance (Oxford, Hart) pp. 205-228.

DTI (2006), Success at Work: Protecting Vulnerable Workers, Supporting Good Employers (London, Department for Trade and Industry).

Fine, J. and J. Gordon (2010), 'Strengthening Labor Standards Enforcement through Partnerships with Workers' Organizations', Politics and Society, 38, 4, 552-585.

Freeman, R. (2005), 'Fighting for Other Folks Wages: The Logic and Illogic of Living Wage Campaigns', Industrial Relations, 44, 1, 14-31.

Frege, C., E. Heery and L. Turner (2004), 'The New Solidarity? Trade Union CoalitionBuilding in Five Countries', in C. Frege and J. Kelly (eds), Varieties of Unionism: Strategies for Union Revitalization in a Globalizing Economy (Oxford, Oxford University Press) pp. $137-158$.

Gall, G. (2012), 'The Engineering Construction Strikes in Britain, 2009', Capital and Class, 36, $3,411-431$.

Gumbrell-McCormick, R. and R. Hyman (2013), Trade Unions in Western Europe: Hard Times, Hard Choices (Oxford, Oxford University Press).

Harvey, M. and F. Behling (2008), The Evasion Economy: False self-employment in the UK construction industry (London, UCATT).

Heery, E., B. Abbott and S. Williams (2012), 'The Involvement of Civil Society Organizations in British Industrial Relations: Extent, Origins and Significance', British Journal of Industrial Relations, 50, 1, 47-72.

Holgate, J., A. Pollert, J. Keles and L. Kumarappan (2012), 'Union Decline and Voice among Minority Ethnic Workers; do Community Support Networks Help Fill the Gap?', Urban Studies, 49, 3, 491-508.

HSE (2013), 'Health and Safety in Construction in Great Britain, 2013: Work-Related Injuries and Ill Health'. Retrieved November 2013 from http://www.hse.gov.uk/statistics/

Kalleberg, A. (2009), 'Precarious Work, Insecure Workers: Employment Relations in Transition', American Sociological Review, 74, 1-22.

Löfstedt, R. (2011), Reclaiming Health and Safety for All: An Independent Review of Health and Safety Legislation (London, Department for Work and Pensions).

MacKenzie, R., C. Forde, A. Robinson, H. Cook, B. Eriksson, P. Larsson and A. Bergman (2010), 'Contingent Work in the UK and Sweden: Evidence from the Construction Industry', Industrial Relations Journal., 41, 6, 603-621.

Mantouvalou, V. (2011), Study on Labour Inspection Sanctions and Remedies: The case of the United Kingdom (Geneva, International Labour Organization).

Martinez Lucio, M. and R. Perrett (2009), 'Meanings and Dilemmas in Community Unionism: Trade Union Community Initiatives and Black and Minority Ethnic Groups in the UK', Work, Employment and Society, 23, 4, 693-710.

McIlroy, J. (2009), 'A Brief History of British Trade Unions and Neoliberalism in the Age of New Labour', in J. McIlroy and G. Daniels (eds), Trade Unions in a Neoliberal World (Abingdon, Routledge) pp. 63-97.

Nichols, T. (1997), The Sociology of Industrial Injury (London, Mansell).

ONS (2012), Office of National Statistics Construction Statistics Annual 2012 (London, ONS).

Pollert, A. and A. Charlwood (2009), 'The Vulnerable Worker in Britain and Problems at Work', Work, Employment and Society, 23, 2, 343-362.

Shearn, K., B. Knight and K. Matharoo (2010), Evaluation of the Vulnerable Workers Pilots Year 2 (Final) Report (London, BIS (Department for Business, Innovation and Skills)). 
Standing, G. (2011), The Precariat: The New Dangerous Class (London, Bloomsbury Academic).

Stuart, M., M. Martinez Lucio, J. Tomlinson and R. Perrett (2010), Union Modernisation Fund-Round Two: Final Evaluation Report (London, BIS (Department for Business, Innovation and Skills)).

Stuart, M., J. Tomlinson and M. Martinez Lucio (2013), 'Women and the Modernization of British Trade Unions: Meanings, Dimensions and the Challenge of Change', Journal of Industrial Relations, 51, 1, 38-59.

Tattersall, A. (2009), 'A Little Help from Our Friends: Exploring and Understanding When Labor-Community Coalitions are Likely to Form', Labor Studies Journal, 34, 4, 485-506.

TUC (2007), Hard Work, Hidden Lives: The Full Report of the Commission on Vulnerable Employment (London, TUC).

Winch, G. (1998), 'The Growth of Self-Employment in British Construction', Construction Management and Economics, 16, 5, 531-542. 